\title{
Effects of rotational closure on coral reef fishes in Waikiki-Diamond Head Fishery Management Area, Oahu, Hawaii
}

\author{
I. D. Williams ${ }^{1,2, *}$, W. J. Walsh ${ }^{2}$, A. Miyasaka ${ }^{2}$, A. M. Friedlander ${ }^{3}$ \\ ${ }^{1}$ Hawaii Coral Reef Initiative, Research Program, University of Hawaii at Manoa, Social Science Research Institute, \\ 2424 Maile Way, 704, Honolulu, Hawaii 96822, USA \\ ${ }^{2}$ Hawaii Division of Aquatic Resources, Honokohau Marina, 74-380B Kealakehe Parkway, Kailua-Kona, Hawaii 96740, USA \\ ${ }^{3}$ NOAA, National Ocean Service, National Centre for Coastal Ocean Science, CCMA, Biogeography Team, \\ and The Oceanic Institute, Makapu'u Point/41-202, Kalanianole Highway, Waimanalo, Hawaii 96725, USA
}

\begin{abstract}
No-take marine reserves can be effective biodiversity conservation and fisheries management tools, but as yet there is little indication of whether rotational management, i.e. alternately closing and opening an area to fishing, might also confer such benefits on coral reef fish stocks. Using data taken from the state of Hawaii's long-term reef monitoring program, we have assessed the effects of more than 2 decades of rotational management on fish stocks at the Waikiki-Diamond Head Fishery Management Area (FMA) on Oahu, Hawaii. Fish biomass tended to increase during the 1 to 2 yr closure periods, but the scale of these increases was insufficient to compensate for declines during open periods. The net effect was that, between 1978 and 2002, total biomass declined by around two-thirds. Coincident with this decline was the virtual disappearance of large fishes $(>40 \mathrm{~cm})$ of fishery-target groups: acanthurids, scarids and mullids. Such fishes, although initially common, were only rarely recorded in surveys after 1990. In 1988, a portion of the FMA was converted into the permanently closed Waikiki Marine Life Conservation District (MLCD). Assessment of the relative effectiveness of permanent and rotational closure is complicated by declines in habitat quality, particularly within the MLCD, caused by overgrowth of much of the reef by the alien algae Gracilaria salicornia, which began in the early 1990s. However, the initial effect of full closure was a reversal of the previous downward trend in fish biomass, and, even in the post habitat-decline period, biomass of target species within the MLCD has been nearly twice as high as in the FMA. Additionally, there have been no declines or even downward trends in maximum size of target families in the MLCD. Overall, rotational management, as implemented at the Waikiki FMA, has not been an effective means of conserving fish stocks or revitalizing public fishing grounds.
\end{abstract}

KEY WORDS: Rotational closure $\cdot$ Marine Protected Area · MPA · Coral reef $\cdot$ Fishing $\cdot$ Hawaii

\section{INTRODUCTION}

From a biodiversity-conservation perspective, there is little doubt that no-take marine reserves can be extremely effective: well-protected reserves generally have more and larger fishes, particularly of fisherytarget species, than comparable unprotected areas or in comparison to pre-closure populations (Polunin \& Roberts 1993, Edgar \& Barrett 1999, McClanahan \&
Arthur 2001, Russ \& Alcala 2003). However, a nearly inevitable consequence of prohibiting fishing will be some cost or loss of utility to excluded user groups including recreational and commercial fishers (Badalamenti et al. 2000, Sladek Nowlis \& Friedlander 2005). Over time, spillover of adult fishes or enhanced export of larvae from no-take reserves may lead to net benefits to fishers in connected areas (McClanahan \& Mangi 2000, Roberts et al. 2001, Russ et al. 2003, 2004, 
Sladek Nowlis \& Friedlander 2005); however, uncertainty as to the likely scale of such benefits in any given situation, together with the fact that protection needs to be effective for an extended period for a reserve to work as a fishery management tool (Russ \& Alcala 1999), means that no-take reserves are not an unproblematic solution to balancing conservation with extractive use.

One at least superficially attractive alternative might be to manage an area by some form of rotational strategy, i.e. alternately opening and closing an area to fishing, the rationale being that fish stocks would recover sufficiently during periods of closure for them to be better able to sustain fishing during open periods. Such a strategy might therefore achieve some conservation goals while mitigating the drawbacks associated with permanent closure. Rotational closures appear to have utility for sedentary invertebrate stocks such as scallops and abalone (Sluczanowski 1984, Myers et al. 2000, Hart 2003), but we are not aware of any previous study on the effectiveness of rotational management of coral reef fish stocks.

Being a populous coastal state with large numbers of commercial, recreational and subsistence fishers, Hawaii has a pressing need for practical and effective marine resource management strategies. Over the past $100 \mathrm{yr}$ the coastal fisheries in Hawaii have undergone enormous changes, including substantial declines in overall catch and size of highly prized and vulnerable species (Shomura 1987, 2004), raising concerns about the long-term sustainability of these stocks (Friedlander \& DeMartini 2002, Friedlander \& Ziemann 2003). Overfishing is often cited as the primary reason for the declining resources, by both general ocean users and commercial fishers themselves (DAR 1988, Harman \& Katekaru 1988, Maly \& Pomroy-Maly 2003). Local experience has shown that rotational closure is much more acceptable to many fishers than permanent closure. In Hawaii and other areas of the Pacific this may partly be due to the perception that temporary closures are a form of traditional resource management, e.g. 'kapu', 'taboo', 'ra'ui' (Johannes 1978, Caillaud et al. 2004). Additionally, rotational closures are viewed as not 'locking away' resources forever (W. J. Walsh pers. obs.). In the 1970 s, resource managers of Hawaii's Division of Aquatic Resources (DAR) considered implementing a rotational-closure strategy for the entire coast of the island of Oahu, with different portions of the coastline closed in different years, but after negotiation with local stakeholders decided instead to introduce rotational management in a much more limited way, i.e. only in the Waikiki-Diamond Head Shoreline Fishery Management Area (FMA), which was established in 1978 (M. Yamamoto, Hawaii DAR, pers. comm.). The stated objectives of the FMA were to preserve, protect, conserve, propagate and manage marine life for the revitalization of public fishing grounds (Division of Fish \& Game 1977).

Herein we use data taken from the long-term monitoring of fish populations in the Waikiki FMA to assess how fish stocks have changed over the course of more than 2 decades of rotational management both in terms of the short-term responses to alternating opening and closing the area, and also over the longer-term. Since in 1988, 10 yr after the creation of the rotationally managed area, a portion of this area was converted into the permanently closed Waikiki Marine Life Conservation District (MLCD), we were able to compare fish populations under those 2 management regimes both before and after the change in management status. Finally, using data taken from a recent large-scale study of Hawaiian coral reefs under different levels of management, we compared fish populations in the rotationally managed FMA, the fully closed MLCD, and from completely unprotected reefs on the southeast coast of Oahu.

\section{MATERIALS AND METHODS}

Study location and management history. The original boundaries of the Waikiki-Diamond Head FMA extended along approximately $2.5 \mathrm{~km}$ of shoreline at the southeastern corner of the island of Oahu, Hawaii, from the high-water mark to 500 yards (457 m) offshore, or to the seaward edge of the fringing reef where this lies further offshore (Fig. 1). For the first $10 \mathrm{yr}$ of its existence, i.e. between 1978 and 1987, the FMA operated on a 4 yr cycle: 2 yr of closure followed by 2 yr in which fishing was permitted, with only hookand-line fishing permitted in the first year, and all forms of fishing except nighttime spearing and gillnetting in the second year. In 1988, a portion of the FMA was converted into a permanently closed area, becoming the Waikiki MLCD (Fig. 1), and the rotational cycle in the area remaining within the FMA was changed to 1 yr open followed by 1 yr closed, with all fishing methods other than gillnetting and nighttime spearing permitted in open years.

The large majority of reef areas within the FMA and MLCD consist of shallow ( $\leq 2 \mathrm{~m}$ ) patch reefs and uncolonized pavement separated by sand patches. Reef condition is currently poor throughout most of this area: coral cover is generally low, and much of the available substrate has been overgrown by macroalgae. However, small areas of fringing reef on the seaward edge of the Waikiki FMA still have moderately high complexity and coral cover (I. D. Williams pers. obs.). Numerous anecdotal reports indicate that habitat quality has declined considerably on Waikiki reefs over the 


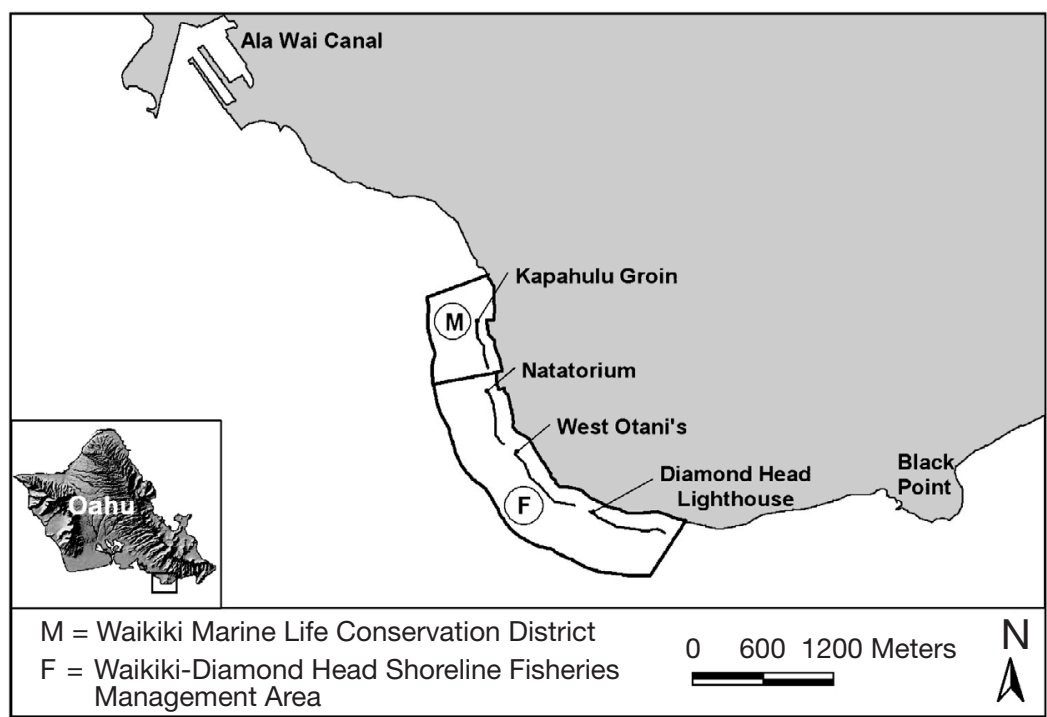

Fig. 1. Current boundaries of the Waikiki-Diamond Head Fishery Management Area (FMA). The FMA extends 500 yards $(457 \mathrm{~m})$ offshore, or to the seaward edge of the fringing reef where this lies further than that distance offshore. Of the 4 transects, 3 (Lighthouse, West Otani's, and Natatorium) were within the FMA for the entire period for which we have data. Reef covered by the Kapahulu transect was within the FMA until 1988, when it became the Waikiki Marine Life Conservation District (MLCD)

Table 1. Status of the Waikiki Fishery Management Area (FMA)/Marine Life Conservation District (MLCD) permanent transects. The FMA was created in 1978; data available from 1979. The FMA alternated between periods of closure (no fishing allowed) and opening (fishing permitted). In 1988, the rotational cycle changed to $2 \mathrm{yr}$ ( $1 \mathrm{yr}$ open followed by $1 \mathrm{yr}$ closed) and the area surveyed by Kapahulu transect became the permanently closed Waikiki MLCD. -: no survey

\begin{tabular}{|c|c|c|c|c|c|}
\hline \multirow{2}{*}{ Year } & \multirow{2}{*}{$\begin{array}{l}\text { FMA } \\
\text { status }\end{array}$} & \multicolumn{4}{|c|}{ No. of surveys conducted per transect } \\
\hline & & Lighthouse & Natatorium & West Otani's & Kapahulu/MLCD \\
\hline 1978 & Closed & \multicolumn{4}{|c|}{ All sites within FMA } \\
\hline 1979 & Closed & 12 & 12 & 12 & 12 \\
\hline 1980 & Open & 13 & 13 & 13 & 13 \\
\hline 1981 & Open & 10 & 10 & 10 & 10 \\
\hline 1982 & Closed & 20 & 21 & 20 & 20 \\
\hline 1983 & Closed & 21 & 21 & 21 & 21 \\
\hline 1984 & Open & 22 & 22 & 22 & 22 \\
\hline 1985 & Open & 15 & 14 & 15 & 15 \\
\hline 1986 & Closed & 11 & 11 & 11 & 11 \\
\hline 1987 & Closed & 9 & 9 & 9 & 9 \\
\hline 1988 & Open & 7 & 7 & 7 & $6^{\mathrm{a}}$ \\
\hline 1989 & Closed & 7 & 7 & 7 & 7 \\
\hline 1990 & Open & 3 & 3 & 3 & 3 \\
\hline 1991 & Closed & - & - & - & - \\
\hline 1992 & Open & - & - & - & - \\
\hline 1993 & Closed & 2 & 2 & 2 & 2 \\
\hline 1994 & Open & - & - & - & - \\
\hline 1995 & Closed & 2 & 2 & 2 & 2 \\
\hline 1996 & Open & 3 & 3 & 3 & 3 \\
\hline 1997 & Closed & 2 & 2 & 2 & 2 \\
\hline 1998 & Open & 2 & 2 & 2 & 2 \\
\hline 1999 & Closed & 3 & 3 & 3 & 3 \\
\hline 2000 & Open & 2 & 2 & 2 & 2 \\
\hline 2001 & Closed & 2 & 2 & 2 & 2 \\
\hline 2002 & Open & 2 & 2 & 2 & 2 \\
\hline \multicolumn{6}{|c|}{$\begin{array}{l}\text { a Kapahulu portion of the FMA became Waikiki MLCD } \\
\text { in } 1988\end{array}$} \\
\hline
\end{tabular}

last 2 decades, but the absence of long-term benthic data means that the cause and timing of this decline are uncertain. A key factor in the apparent decline, particularly within the MLCD, has almost certainly been overgrowth of much of the reef by the alien alga Gracilaria salicornia. G. salicornia, which is relatively unpalatable to Hawaiian herbivorous fishes, was introduced in a limited way onto Waikiki reefs in 1971 for experimental aquaculture, but has since become the dominant benthic organism in large portions of the MLCD and, to a lesser extent, in adjacent areas of the FMA (Smith et al. 2004).

The small amount of quantitative information on algal abundance which we have been able to obtain comes from a single transect located within $50 \mathrm{~m}$ of the current boundary between the FMA and the MLCD which has been sporadically surveyed by University of Hawaii students since 1975. At this location, Gracilaria salicornia populations exploded sometime between 1990 and 1995: having not been recorded at all between 1975 and 1990, it had become the dominant alga by 1995 and has remained so in all subsequent surveys, with wet weight varying between 0.4 and $1.8 \mathrm{~kg} \mathrm{~m}^{-2}$ (R. A. Kinzie unpubl. data).

Monitoring. Staff of Hawaii's DAR have monitored fish populations in back-reef and reef-flat areas of the FMA and MLCD using an unvarying methodology throughout: 4 nearly contiguous transects with fixed start and end points, covering almost the entire length of the managed area, and varying in length between 450 and $600 \mathrm{~m}$, have been surveyed annually, generally several times per year, by pairs of snorkellers swimming in parallel and counting all fishes within non-overlapping $10 \mathrm{ft}$ ( $3 \mathrm{~m}$ )-wide belts (1.5 $\mathrm{m}$ on either side of each observer). For all fishes observed, fish sizes were estimated to the nearest inch $(2.5 \mathrm{~cm})$. Counts from the 2 observers were then pooled and recorded on a single data sheet per transect per survey. Between 1979 and 1986 each transect was sur- 
veyed more than 10 times (Table 1), but frequency of sampling subsequently declined: since 1990 transects have generally been surveyed only twice a year, and there are no data for 1978, 1991, 1992 or 1994. Over the $23 \mathrm{yr}$ for which we present data, there was a steady turnover of survey staff, so that in total more than 30 different observers worked on the program. While differences among observers can be a source of survey error (Kulbicki \& Sarramegna 1999), we see no reason to believe that such regular changes in staff would have introduced any consistent bias.

Data-handling and analysis. The boundary between the FMA and the MLCD is near the end of the original 'Kapahulu' transect (Fig. 1). Therefore, only 3 of 4 transects (Natatorium, West Otani's, and Lighthouse: Table 1, Fig. 1) were within FMA boundaries throughout the entire period for which we have data. So that assessments of long-term trends within the FMA are for the same areas throughout, all estimates of FMA biomass or abundance are based on surveys of these 3 transects only. The reef area surveyed on the other transect (Kapahulu) was originally within the FMA, but has been permanently closed to fishing since the MLCD was established in 1988, and therefore biomass and abundance estimates for the area are henceforth designated 'Kapahulu/MLCD'.

For the purposes of analysis, fish survey data were pooled into a number of broad categories: (1) all fish combined; (2) family; or (3) fishery-target or non-target species. Fishery-target species used in the analysis are listed in Table 2.

The majority of the results are based on estimated biomass of fishes, calculated using size-toweight conversion parameters from FISHBASE (FISHBASE 2000; available at www.fishbase.org/ home.htm) or the Hawaii Co-operative Fisheries Research Unit at the University of Hawaii.

Pelagic or semipelagic fishes, specifically scombrids, sharks, sardines, anchovies and the Hawaiian ladyfish Elops hawaiensis, were excluded from analyses of monitoring data on the basis that (1) they were presumed to be passing through rather than being in any meaningful way resident in the surveyed areas, and (2) they were only rarely encountered, but tended to have very high biomass when present, such that they overwhelmed the biomass of resident reef fishes in those counts in which were present. Additionally, relatively low sampling replication within the MLCD, particularly from 1990 onwards (Table 1) meant that MLCD data were prone to large variability due to occasional encounters with schools of rare but high-biomass fishes. Therefore, 2 such species (Acanthurus xanthopterus and Caranx ignobilis) were excluded from estimates of target species biomass. These species together averaged less than $1 \%$ of the total target species biomass in the FMA and MLCD over the full sampling period, but both dominated estimated MLCD fish biomass in single years: A. xanthopterus making up $55 \%$ of total MLCD biomass in 2002; and C. ignobilis being $43 \%$ of MLCD biomass in 1996.

Analysis of trends in the maximum size of fishes in 3 families targeted by fishers (acanthurids, scarids, mullids) were calculated by first determining the size of the largest individual in each of these families in each survey, and then calculating annual means of those values for the area of interest.

Table 2. Fishery-target species used in analysis

\begin{tabular}{|ll|}
\hline Family, Taxon & Family, Taxon \\
\hline Acanthuridae & Holocentridae \\
Acanthurus achilles & Myripristis berndti \\
Acanthurus blochii & Myripristis kuntee \\
Acanthurus dussumieri & Sargocentron spiniferum \\
Acanthurus guttatus & Sargocentron tiere \\
Acanthurus leucopareius & Labridae \\
Acanthurus nigroris & Anampses cuvier \\
Acanthurus olivaceus & Bodianus bilunulatus \\
Acanthurus triostegus & Coris flavovittata \\
Acanthurus xanthopterus & Novaculichthys taeniourus \\
Ctenochaetus hawaiiensis & Oxycheilinus unifasciatus \\
Ctenochaetus strigosus & Thalassoma ballieui \\
Zebrasoma flavescens & Thalassoma duperrey \\
Zebrasoma veliferum & Thalassoma purpureum \\
Naso brevirostris & Xyrichtys spp. \\
Naso hexacanthus & Others \\
Naso lituratus & Albula spp. \\
Naso unicornis & Melichthys niger \\
Scaridae & Melichthys vidua \\
Calotomus carolinus & Chanos chanos \\
Calotomus zonarchus & Fistularia commersonii \\
Chlorurus perspicillatus & Monotaxis grandoculis \\
Chlorurus sordidus & Lutjanus fulvus \\
Scarus dubius & Lutjanus kasmira \\
Scarus psittacus & Aluterus scriptus \\
Scarus rubroviolaceus & Mugil cephalus \\
Mullidae & Abudefduf abdominalis \\
Mulloidichthys flavolineatus & Abudefduf sordidus \\
Mulloidichthys vanicolensis & Heteropriacanthus cruentatus \\
Parupeneus bifasciatus & Priacanthus meeki \\
Parupeneus cyclostomus & Priacanthus sp. \\
Parupeneus multifasciatus & Cephalopholis argus \\
Parupeneus porphyreus & Sphyraena barracuda \\
Carangidae & \\
Carangoides ferdau & \\
Caranx ignobilis & \\
Caranx lugubris & \\
Caranx melampygus & \\
Decapterus macarellus & \\
Selar crumenophthalmus & \\
\hline
\end{tabular}


Long-term trends in biomass, abundance, and maximum length were analyzed using Spearman's rank correlation test. Comparisons between fish populations in FMA and Kapahulu/MLCD were made using paired $t$-tests of estimated fish biomass, the pairs being FMA and Kapahulu/MLCD data from the same year. Assessment of the significance of changes in biomass during alternating periods of closure/opening to fishing were based on paired $t$-tests of data calculated from fish surveys during the last 6 mo of any fished or protected period. For example, the test of the effects of closure was based on biomass data from the last 6 mo prior to each closure period, i.e. July to December 1981, July to December 1985, etc., paired in each case with data from the last 6 mo of the subsequent closed period i.e. July to December 1983, July to December 1987, etc. (Table 3). We did not use earlier data in the openclosed cycles because we wanted to maximize the period of time in which fishing/closure could affect fish populations while still selecting data covering a period long enough to allow sufficient surveys and thus reasonable estimates of fish biomass.

Data from other surveys at FMA, MLCD and Waikiki 'open' reefs. In addition to the long-term monitoring data for Waikiki FMA and MLCD, we also use data from an ongoing study conducted by the National Oceanic and Atmospheric Administration (NOAA), DAR and partners to evaluate the efficacy of marine park areas (MPAs) in
Hawaii. During the ongoing study, between January and April 2002 fishes and habitat were surveyed along 99 transects $(25 \times 5 \mathrm{~m}$ each $)$ in the Waikiki study area, i.e. Black Point to the Ala Wai Canal (Fig. 1). The Waikiki MLCD (31 ha) and the FMA (97 ha) comprise approximately 4 and $13 \%$ respectively of that area (728 ha, Fig. 1). A random sampling approach was utilized with samples stratified by management regime (MLCD, FMA, open to all fishing) and major habitat type (>10\% live coral hard-bottom; $<10 \%$ live coral hard-bottom, sand, and macroalgae) using NOAA's GIS (Geographic Information System)-based benthic habitat maps (A. M. Friedlander et al. unpubl.). The minimum mapping unit (MMU) for habitat polygons was 1 acre $\left(4046.9 \mathrm{~m}^{2}\right)$ (Coyne et al. 2003). Habitat diversity at each survey location was calculated as the Shannon-Wiener diversity index $H^{\prime}$ in ArcView, using areal cover of classified habitat types from the NOAA's benthic habitat maps and 100 and $200 \mathrm{~m}$ buffer areas around each sampling location.

A 1-way ANOVA was used to compare habitat diversities $\left(H^{\prime}\right)$ among management regimes. A comparison of fish biomass among management regimes was conducted using a nested ANOVA, with the 2 habitat types common to all 3 management strata (macroalgae; and $<10 \%$ live coral, hard bottom) nested within management strata. Fish biomass $\left(\mathrm{t} \mathrm{ha}^{-1}\right)$ was $\ln (x+1)$-transformed prior to analysis. Unplanned multiple comparisons were tested using Tukey's HSD test $(\alpha=0.05)$.
Table 3. Changes in biomass of fishery-target species during closed/ open periods based on data for last 6 mo of relevant closed/open period. Net declines are underlined. No data for 1991, 1992 or 1994

\begin{tabular}{|c|c|c|c|c|c|}
\hline \multirow[t]{3}{*}{ Period } & \multirow{3}{*}{$\begin{array}{l}\text { FMA } \\
\text { status }\end{array}$} & \multicolumn{4}{|c|}{ Biomass $\left(\mathrm{g} \mathrm{m}^{-2}\right)$} \\
\hline & & \multicolumn{2}{|c|}{ Last 6 mo } & \multicolumn{2}{|c|}{ Change while } \\
\hline & & $\begin{array}{l}\text { prior to } \\
\text { this period }\end{array}$ & $\begin{array}{l}\text { of this } \\
\text { period }\end{array}$ & open & closed \\
\hline $1980-81$ & Open & 53.6 & 37.0 & -16.6 & \\
\hline $1982-83$ & Closed & 37.0 & 49.4 & & 12.5 \\
\hline $1984-85$ & Open & 49.4 & 24.2 & -25.2 & \\
\hline 1986-87 & Closed & 24.2 & 40.9 & & 16.7 \\
\hline 1988 & Open & 40.9 & 23.2 & -17.8 & \\
\hline 1989 & Closed & 23.2 & 32.5 & & 9.3 \\
\hline 1990 & Open & 32.5 & 26.5 & $-\underline{6.0}$ & \\
\hline 1996 & Open & 15.0 & 25.1 & 10.1 & \\
\hline 1997 & Closed & 25.1 & 25.4 & & -9.7 \\
\hline 1998 & Open & 15.4 & 14.5 & $-\underline{0.9}$ & \\
\hline 1999 & Closed & 14.5 & 20.0 & & 5.5 \\
\hline 2000 & Open & 20.0 & 5.6 & -14.4 & \\
\hline 2001 & Closed & 5.6 & 16.0 & & 10.4 \\
\hline 2002 & Open & 16.0 & 10.2 & $\underline{-5.8}$ & \\
\hline Mean & & & & $-\underline{9.6}$ & 7.4 \\
\hline $\mathrm{SD}$ & & & & 11.2 & 9.2 \\
\hline \multicolumn{6}{|c|}{ Paired $t$-tests } \\
\hline df & & & & 7 & 5 \\
\hline$t$-ratio & & & & -2.43 & 1.99 \\
\hline $\mathrm{p}$ & & & & 0.02 & $<0.05$ \\
\hline
\end{tabular}

\section{RESULTS}

\section{Trends in fish biomass and abundance}

Within the FMA, fish biomass and abundance both declined substantially between 1979 and 2002 (Fig. 2: biomass $R_{\mathrm{S}}$ [Spearman's rank correlation coefficient] $=-0.83$; abundance $R_{\mathrm{S}}=-0.81$, both $\mathrm{p}<0.001$ ). By the end of this period, fish biomass was about one-third of that recorded in the early years of the FMA, having declined from around 60 $\mathrm{g} \mathrm{m}^{-2}$ in the early 1980 s to around $20 \mathrm{~g} \mathrm{~m}^{-2}$ in 2002 (Fig. 2A). The absolute scale of the decline in abundance has been somewhat smaller, from 0.3 to $0.4 \mathrm{~m}^{-2}$ in the early $1980 \mathrm{~s}$, to around $0.2 \mathrm{~m}^{-2}$ in 2002, Fig. 2B).

\section{Trends in family and 'target' and 'non-target' species}

There were clear differences between families frequently targeted by fishers, i.e. acanthurids, scarids, mullids, and carangids 
(Fig. 3A-D), and families that are not as heavily fished, i.e. labrids, balistids, chaetodontids and pomacentrids (Fig. 3E-H). Sharp declines in the biomass of target families were evident during the early years of the FMA, but since the mid-1990s, the biomass of these
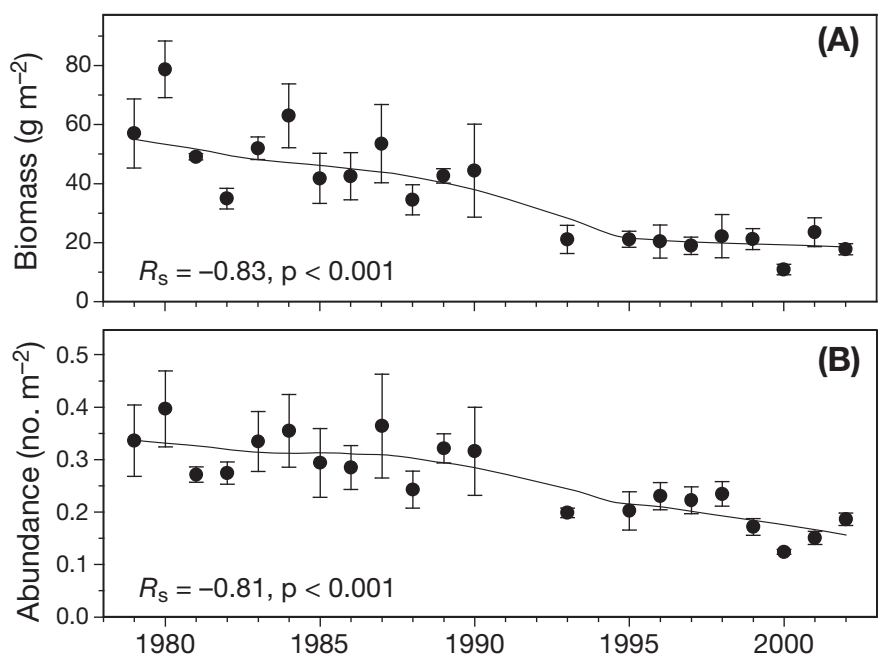

Fig. 2. Annual mean ( $\pm \mathrm{SE}$ ) (A) biomass and (B) abundance of all fishes in the FMA. Trend lines generated using LOESS smoothing function. Here and elsewhere, FMA data are only for the 3 transects that lay within the FMA for the whole period for which we have data families appears to have leveled off. In contrast, the biomass of the less heavily fished groups generally increased in the early years after establishment of the FMA, but has declined since the mid-1980s (Fig. 3E-H). With the possible exception of pomacentrids, the net effect has been relatively little overall change in the biomass of these non-target families over the full period for which we have data.

Fish biomass pooled into 'fishery-target' and 'nontarget' groups corroborate these patterns (Fig. 4). Among target species, the scale of decline between 1979 and 2002 was dramatic, biomass having declined from 40 to $50 \mathrm{~g} \mathrm{~m}^{-2}$ in the early years after creation of the FMA to around $10 \mathrm{~g} \mathrm{~m}^{-2}$ in recent years (Fig. 4A).

\section{Short-term changes during closed and open periods}

Within the FMA, the biomass of fishery-target species has tended to increase during periods of closure, and decrease during open periods (Fig. 5, Table 3, paired $t$-tests $\mathrm{p}<0.05$ in both cases). However, the extent of the declines during the open periods has been greater than that of increases in the closed periods, and the net effect therefore has been a sawtooth pattern overlying an overall downward trend (Fig. 5).
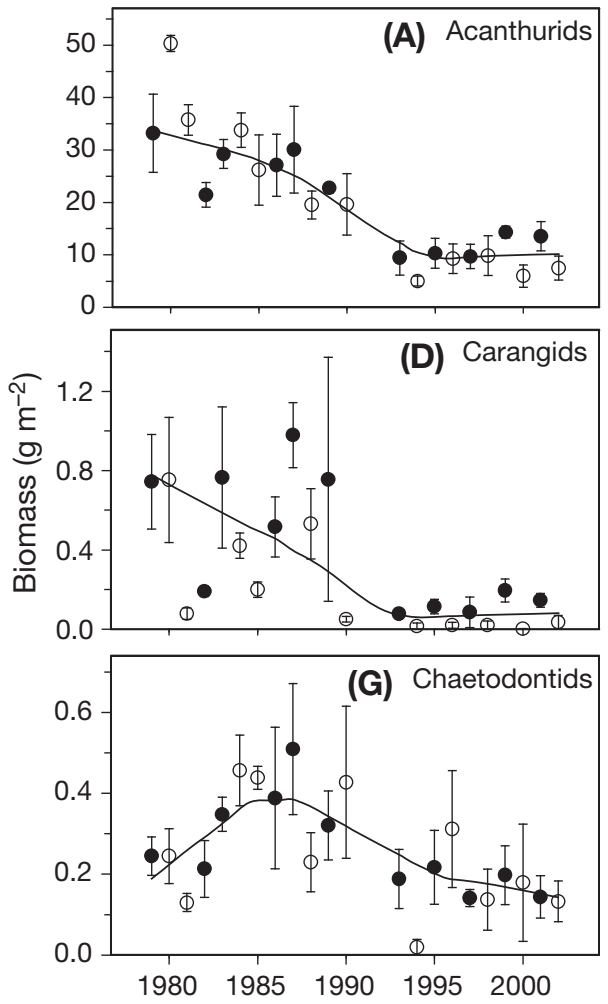
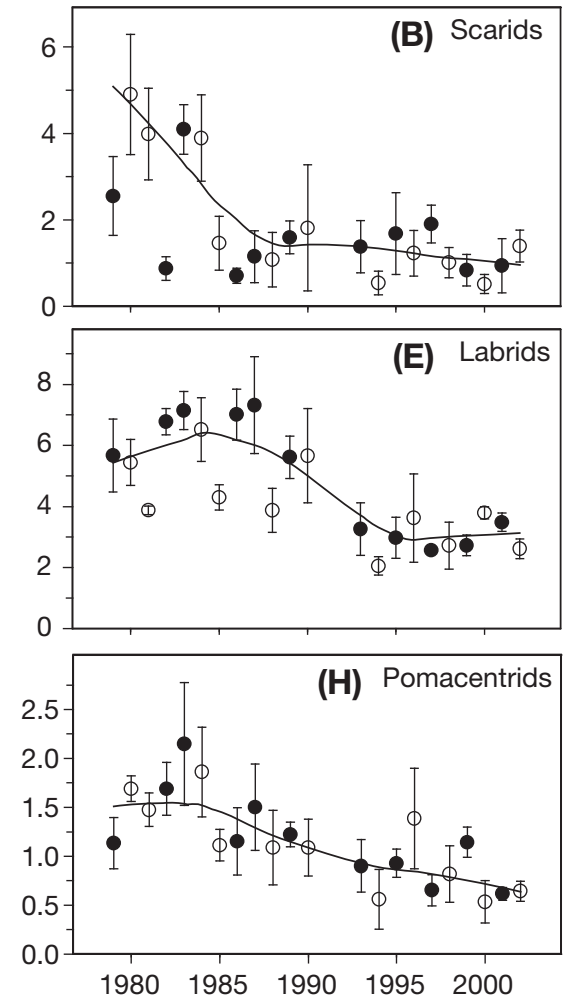
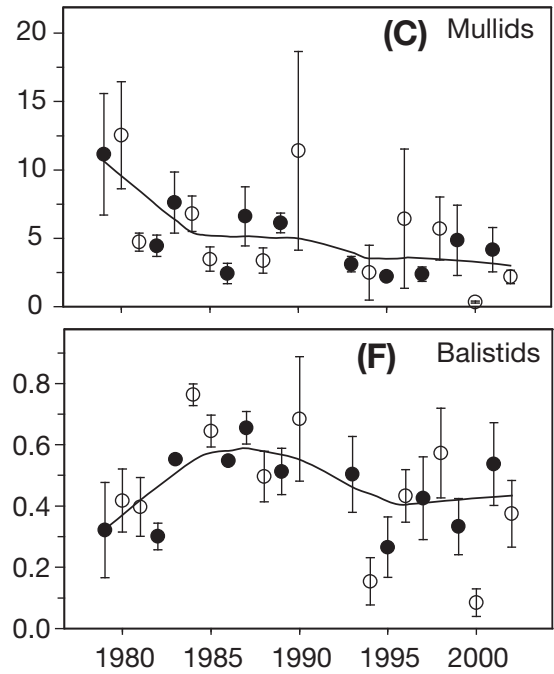

- Closed
o Open

Fig. 3. Annual mean $( \pm \mathrm{SE})$ biomass of families in the FMA. Trend lines generated using LOESS smoothing function 

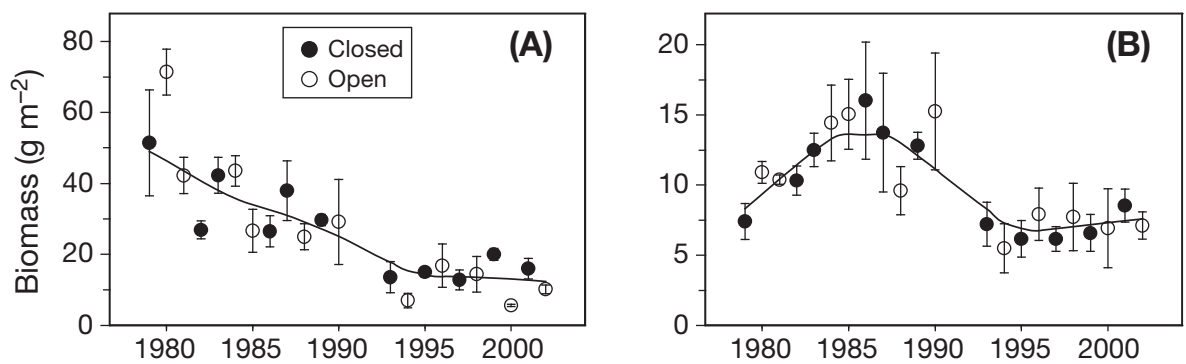

Fig. 4. Annual mean $( \pm \mathrm{SE})$ biomass of $(\mathrm{A})$ fishery-target and $(\mathrm{B})$ non-target fishes in the FMA. Trend lines generated using LOESS smoothing function

\section{Biomass of fishery-target species}

Between 1979 and 1987, the biomass of fisherytarget species declined on both the FMA transects and the Kapahulu transect (Fig. 6, Period i: both areas rotationally managed). During this period, there was no difference in target species biomass between the FMA transects and the Kapahulu transect (Fig. 6C, Table 4). Within the first few years after the creation of the MLCD, target species biomass increased dramatically within the MLCD, remaining relatively flat in the FMA (Fig. 6, Period ii): between 1988 and 1990, the biomass of target species averaged nearly $40 \mathrm{~g} \mathrm{~m}^{-2}$ more in the MLCD than in the FMA (Fig. 6C, Table 4). There are very few data for the years between 1990 and 1995, but during that period, which coincided with the presumed period of proliferation of invasive algae in the MLCD, the biomass of fishery-target species declined substantially within the MLCD. However, even in the post habitatdecline period (Fig. 6C, Period iii), target species biomass was significantly higher in the MLCD than in the FMA (Table 4).

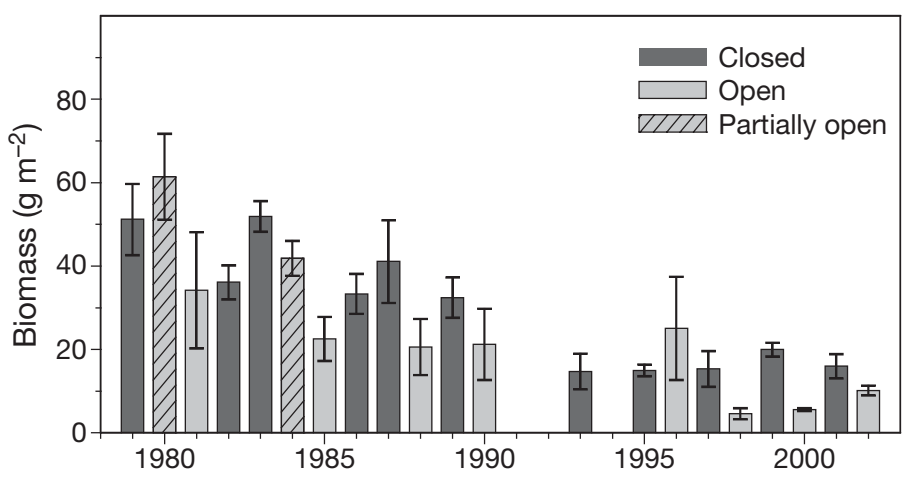

Fig. 5. Annual mean (+SE) biomass of fishery-target species in the FMA, July to December data only. Closed: years in which the FMA was fully closed to fishing; Partially open: years in which only hook-and-line fishing was permitted; Open: years when FMA was open to all forms of fishing other than gillnetting and nighttime spearing

\section{Trends in maximum fish size}

Coincident with the downward trend in biomass within the FMA were substantial reductions in the size of the largest fishes observed during surveys. In the early $1980 \mathrm{~s}, 40$ to $50 \mathrm{~cm}$ acanthurids and scarids were commonly observed during fish-counts, but in recent years the maximum size recorded per survey has averaged around $30 \mathrm{~cm}$ for acanthurids and less than $20 \mathrm{~cm}$ for scarids (Fig. 7). Very large scarids (>50 cm), which were regularly encountered between 1979 and 1985 (115 of 376 surveys $=31 \%$ ), have virtually disappeared from the FMA: individuals of this size have been recorded in only 3 of 78 surveys conducted since 1990. Less dramatic, but still significant declines in maximum size have also occurred in mullids (Fig. 7). In contrast, there have been no declines or even downward trends in the maximum size of any of these families in the area now within the MLCD (Fig. 7).

\section{Reef habitats and fish assemblages}

Macroalgae habitats, as defined by the NOAA benthic habitat maps, accounted for $39.7 \%$ of the total habitat within the MLCD but only $17.4 \%$ within the FMA, and $14.7 \%$ overall. There was no coral reef habitat $(>10 \%$ live coral cover as defined by the NOAA benthic habitat maps, which have a minimum mapping unit of 1 acre [4046.9 $\left.\mathrm{m}^{2}\right]$ ) within the MLCD, but this habitat type accounted for $16.4 \%$ of the total habitat within the FMA, and $13.5 \%$ over the entire study area. Samples taken in the FMA had the highest mean habitat diversity among the 3 management regimes, and open-access areas the least (FMA: $H^{\prime}=0.70 \pm 0.48 \mathrm{SD}$, MLCD: $H^{\prime}=0.57 \pm 0.28$; open $H^{\prime}=0.48 \pm 0.32 ; F_{2,96}=$ 3.28, $\mathrm{p}=0.04, \mathrm{FMA} \geq \mathrm{MLCD} \geq$ open).

Total fish biomass, from all habitats pooled, was $51 \%$ higher inside the MLCD than within the FMA and $63 \%$ higher than areas open to all fishing. Statistical differences in overall fish biomass were detected between the MLCD and the 2 other management strata, but no 
(A) Waikiki-Diamond Head FMA

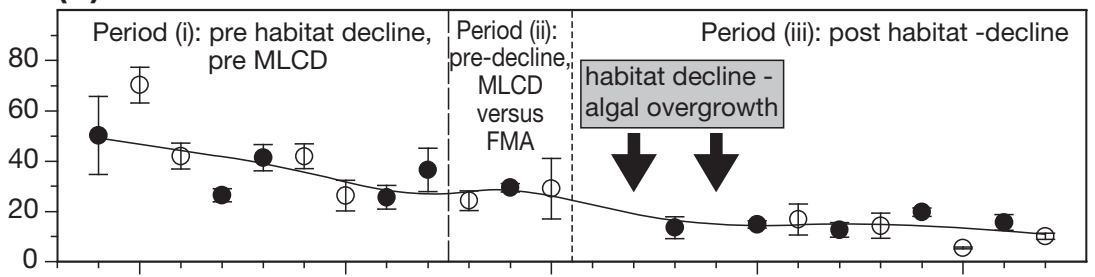

(B) 'Kapahulu' portion of FMA ......... becoming Waikiki MLCD in 1988

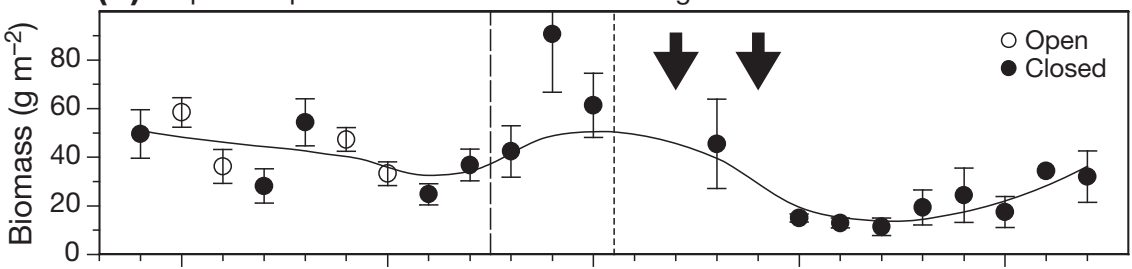

(C) Difference in biomass between Kapahulu/MLCD and Waikiki-Diamond Head

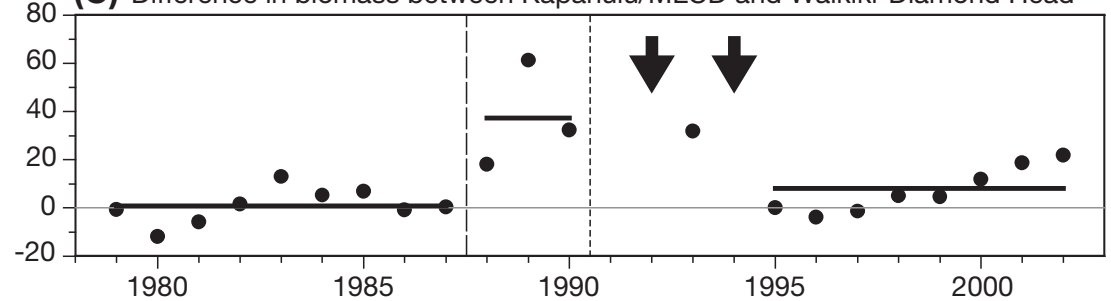

Fig. 6. Annual mean $( \pm \mathrm{SE})$ biomass of fishery-target species in the FMA and Kapahulu/MLCD. First dashed vertical line: year (1988) that the Kapahulu portion of the FMA became the Waikiki MLCD; second dashed vertical line: onset of presumed habitat decline. Horizontal lines in (C): averages over 3 periods. Trend lines in (A) and (B) generated using LOESS smoothing function difference was detected between the FMA and open areas (Table 5). These differences were also evident in both habitat types common to all 3 management strata, with the MLCD possessing the highest biomass, and the open-access areas having the lowest biomass in both the macroalgae and $<10 \%$ live coral hard-bottom habitats (Table 5).

\section{DISCUSSION}

The evidence from the Waikiki FMA, that increases in fish biomass during the 1 or 2 yr closure periods were insufficient to compensate for declines during the equally short fishing periods (Table 3), is consistent with a number of studies demonstrating that increases in biomass built up over several years of protection can be rapidly dissipated following the resumption of fishing. For example, the Sumilon Island Reserve in the Philippines has been closed to fishing since 1974, except for 2 periods when protection broke down, beginning in 1984 and 1992. In both instances, increases in fish biomass, which had built up over 9.5 and 5 yr respectively, were completely eliminated 18 mo to 2 yr after the breakdown of protection (Russ \& Alcala 1998). Similarly, following the reduction in size of a 4 yr old marine reserve in Mombassa, Kenya, initially high catch rates in the previously closed area lasted for only a few months after reopening (McClanahan \& Mangi 2000).

The severe decline in the maximum observed size of target fishes in the FMA clearly indicates that 1 to $2 \mathrm{yr}$ closure periods were too short for individuals of these species to grow to anywhere near maximum size. There are, more generally, a number of reasons for believing that 1 or 2 yr periods of closure are too short for substantial recovery of coral reef fish stocks. Russ \& Alcala (1996), in a long-term study of 2 Philippine marine reserves, found that the largest increases in biomass of target fishes occurred after 5 or more years

Table 4. Paired FMA versus Kapahulu/MLCD comparisons. Positive mean difference (diff.) indicates greater biomass in Kapahulu/MLCD than in FMA

\begin{tabular}{llcccc}
\hline Period & Comparison & $\mathrm{N}$ & $\begin{array}{l}\text { Mean } \pm \text { SE } \\
\text { diff. }\left(\mathrm{g} \mathrm{m}^{-2}\right)\end{array}$ & df:t-ratio & $\mathrm{p}(1$-tailed) \\
\hline (i) 1979-1987 & Pre-MLCD: FMA vs. Kapahulu & 9 & $0.9 \pm 2.4$ & $8: 0.39$ \\
(ii) 1988-1990 & Pre-habitat decline: FMA vs. Waikiki MLCD & 3 & $37.2 \pm 12.7$ & $2: 2.93$ & 0.36 \\
(iii) 1995-2002 & Post-habitat decline: FMA vs. Waikiki MLCD & 8 & $7.1 \pm 3.3$ & $7: 2.14$ & 0.04 \\
\hline
\end{tabular}




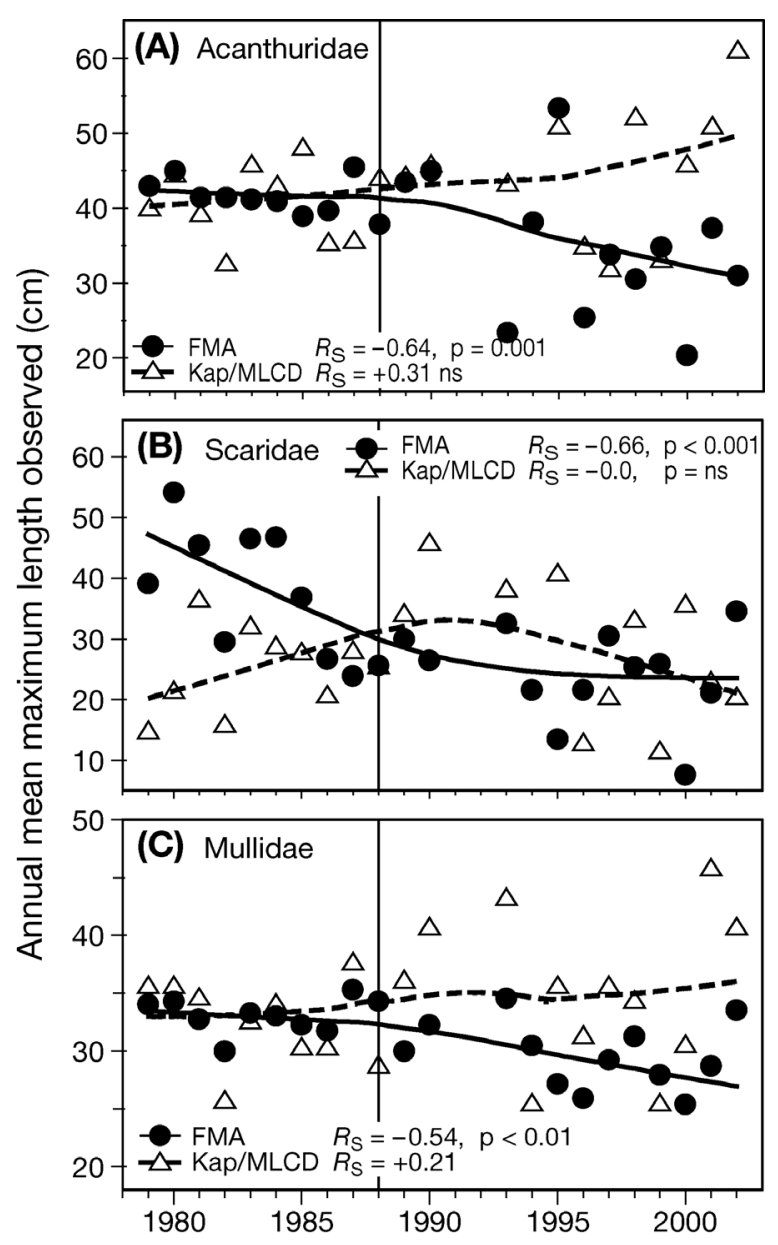

Fig. 7. Trends in maximum recorded size of fishes in 3 families in the FMA and Kapahulu/MLCD. Vertical line: year (1988) of MLCD establishment. Trend lines generated using LOESS smoothing function. Continuous line: trend in FMA; dashed line: trend in Kapahulu/MLCD area. ns = not significant

Table 5. Comparison of fish biomass ( $\mathrm{ha}^{-1}$ ) among management regimes and habitat types, showing results of nested ANOVA with major habitat types common to all management regimes nested within management regime $(\mathrm{N}=74)$. Biomass $\ln (x+1)$ transformed prior to analysis. Management regimes: MLCD $(\mathrm{M})$; FMA $(\mathrm{F})$; Open (completely open to fishing [O]). Habitat strata: $<10 \%$ live coral hard-bottom (UHB); and macroalgae (MAC). Unplanned multiple comparisons among management strata and habitat (management) tested using Tukey's HSD tests. Underlined values are not significantly different $(\alpha=0.05)$

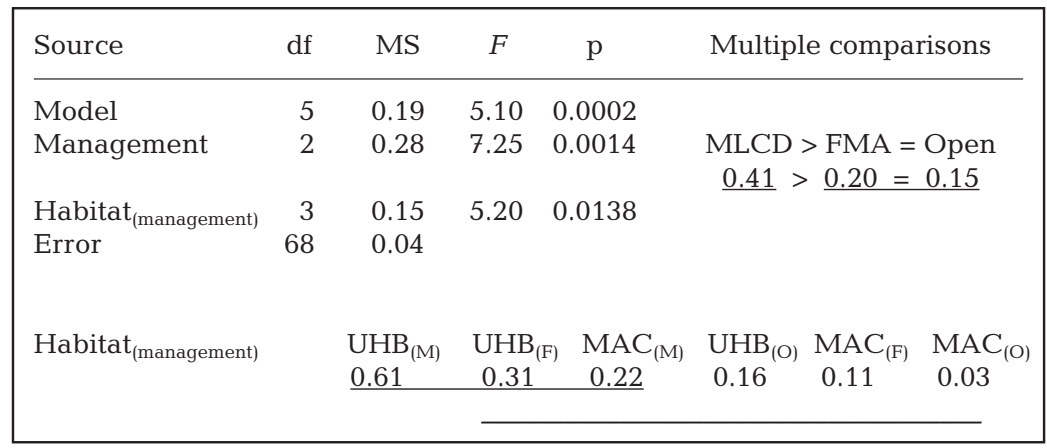

of protection. They presumed that this was a consequence of delayed recruitment effects and that, in the first few years of protection, the fish stocks were dominated by very young fishes which do not accumulate as much biomass as fishes aged from 2 to 4 yr. While it might be possible to increase closure benefits of a rotational strategy by extending the duration of the closed period beyond the 1 or 2 yr implemented at Waikiki, it is important to recognize that full recovery in terms of ecological function, community structure, and total biomass, particularly of large predatory fishes, is likely to take 10 or more years following cessation of fishing (McClanahan 2000, McClanahan \& Arthur 2001, Russ \& Alcala 2004, McClanahan \& Graham 2005). Large fishes are not only prime fishery targets, but are also particularly important in terms of community fecundity (Sadovy 1996, Birkeland \& Dayton 2005), ecological role (Friedlander \& DeMartini 2002, DeMartini et al. 2005) and their value to marine tourism (Williams \& Polunin 2000). Therefore, several fundamental conservation and management goals are unlikely to be achievable under any feasible rotational closure regime.

The paucity of long-term benthic data from surveyed areas makes it difficult to draw firm conclusions about the extent of, or consequences of, changes in habitat quality on Waikiki reefs. Over the period 1990 to 1995, when, it seems, MLCD reefs were becoming overgrown by Gracilaria salicornia, biomass of fishery-target species in the MLCD declined by about half. It is not unrealistic to suppose that much of that decline was driven by reduced habitat uality (perhaps in combination with reduced availability of more palatable algal species), as the direct consequences of overgrowth of the reef by 5 to $10 \mathrm{~cm}$ thick mats of G. salicornia (Smith et al. 2004) would include smothering of corals and infilling of crevices and holes in the reef, and subsequent reduction in the kind of structural complexity that appears to be necessary for reefs to sustain large and diverse fish populations (Friedlander \& Parrish 1998, Friedlander et al. 2003). Until at least 1990, target species biomass on the Kapahulu/MLCD reef consistently increased during closed periods, so it seems implausible that there would be such a dramatic drop in biomass between 1990 and 1995 without some reduction in either protection level or habitat quality, and we have no reason to believe that protection was any less effective post-1990. 
The onset of Gracilaria salicornia overgrowth so soon after the establishment of the MLCD complicates any assessment of the relative effectiveness of rotational and permanent closure of Waikiki reefs. There are, however, a number of reasons to believe that despite its small size (the length of shoreline within MLCD is $<700 \mathrm{~m}$ ) and the probable impact of invasive algae, the MLCD has been considerably more effective than the FMA in conserving fish stocks: (1) since its inception, the biomass of target fishes has been consistently higher in the MLCD than in the FMA, even though there were no differences between these 2 areas when both lay within the original boundaries of the FMA (Fig. 6, Table 4); (2) in contrast to the FMA, there were no net declines or downward trends in maximum size of target fishes in the MLCD (Fig. 7); (3) in both habitat types common to the FMA and the MCLD in the larger-scale 2002 study ('macroalgae' and 'unconsolidated hard bottom'), mean fish biomass in the MLCD was approximately twice that in the FMA (Table 5). Whether fish stocks within the Waikiki FMA derived any persisting benefits from the 1 to 2 closure periods is difficult to judge. The only comparable data we have from the FMA and from fully unprotected areas on southeastern Oahu are for the large-scale 2002 survey, when FMA reefs had a non-significantly higher biomass of fishes than completely unprotected reefs (Table 5), but also a higher habitat diversity and greater structural complexity. It seems likely, therefore, that any sustained benefits of rotational closure were marginal at best. It is even possible that, by attracting 'derby fishing' (i.e. pulses of intensive fishing immediately after areas are reopened: Meyer 2003), rotational closure might be counterproductive in this regard.

Even if rotational closure were unlikely ever to be an effective conservation strategy, it could still achieve other management goals. For example, closing an area to fishing for short to medium time periods could be a means of increasing yield per recruit by allowing fish to grow before they become vulnerable to capture (McCallum 1988, Myers et al. 2000). However, the findings of a 1998 to 2001 study of fishing activities in the FMA, MLCD and comparable fully open areas in southeastern Oahu (Meyer 2003) do not support the idea that the Waikiki FMA has been effective in this regard either. Although fishing effort and total yield $\left(\mathrm{t} \mathrm{km}^{-2}\right.$ ) were higher in the FMA than in fully open areas on the south coast of Oahu, catch per unit effort (CPUE) was actually lower in the FMA. The majority of yields, including almost all large individuals caught, came from small areas of structurally complex habitat on the seaward edge of fringing reefs, which were much more developed in the FMA than in the otherwise comparable fully open reefs (Meyer 2003). There- fore, the lower CPUE in the FMA occurred despite the better habitat quality of this area. Additionally, net yield from the FMA was very low in absolute terms, averaging $0.58 \mathrm{t} \mathrm{km}^{-2} \mathrm{yr}^{-1}$ between 1998 and 2001 (Meyer 2003). Such low yield partially reflects the poor quality of much of the reef habitat at Waikiki, but is nevertheless an order of magnitude lower than published yields for fringing reefs elsewhere in Hawaii and the Pacific: Friedlander \& Parrish (1997) estimated a yield of $3.6 \mathrm{t} \mathrm{km}^{-2} \mathrm{yr}^{-1}$ from reefs in Hanalei Bay, Kauai, in 1992 to 1993, and other studies of yields from small fringing reefs around the Pacific range from 4.5 to $44.0 \mathrm{t} \mathrm{km}^{-2} \mathrm{yr}^{-1}$ (Dalzell 1996).

In summary, despite short-term boosts to fish stocks and possibly also to fishers during or immediately after 1 to 2 yr periods of closure, the longer-term consequences of alternately opening and closing the Waikiki FMA have been very substantial declines in the biomass of fishery-target groups, together with the virtual disappearance of larger individuals of these groups. Rotational management, as implemented at Waikiki FMA, has not been an effective means of conserving fish stocks or revitalizing public fishing over the longer term.

Acknowledgements. Support for I.D.W. came from the National Oceanic and Atmospheric Administration, Center for Sponsored Coastal Ocean Research, awards NA03NOS 4260044 and NA04NOS4260172 to the University of Hawaii for the Hawaii Coral Reef Initiative Research Program (HCRIRP). The data used in this paper are from the State of Hawaii's Division of Aquatic Resources (DAR) long-term coral reef monitoring program and from the Fish Habitat Utilization Study funded by DAR and NOAA. We are therefore particularly grateful to DAR staff members, including Brian Kanenaka, Mike Yamamoto, Francis Oishi, Jason Leonard, Rodney Young, Paul Murakawa, Jo-Anne Kushima, and Eric Brown, who gathered the majority of the data presented here. We thank Dr. Kinzie for access to his long-term algal survey data. Laura Livnat, Jill Zamzow, Eric Conklin and Carl Meyer provided helpful comments on earlier drafts of this manuscript. Lisa Wedding prepared Fig. 1.

\section{LITERATURE CITED}

Badalamenti F, Ramos AA, Voultsiadou E, Lizaso LJS and 6 others (2000) Cultural and socio-economic impacts of Mediterranean marine protected areas. Environ Conserv 27:110-125

Birkeland C, Dayton PK (2005) The importance in fishery management of leaving the big ones. Trends Ecol Evol 20: 356-358

Caillaud A, Boengkih S, Evans-Illidge E, Genolagani J and 14 others (2004) Tabus or not taboos? How to use traditional environmental knowledge to support sustainable development of marine resources in Melanesia. SPC Traditional Mar Resour Manag Knowledge Inf Bull 17:14-35

Coyne MS, Battista TA, Anderson M, Waddell J, Smith W, Jokiel P, Kendall MS, Monaco ME (2003) Benthic habitats of the main Hawaiian Islands. NOAA Tech Memo NOS. Available at: http://ccmaserver.nos.noaa.gov/ products/biogeography/hawaii_cd/htm/overview.htm\#intro 
Dalzell P (1996) Catch rates, selectivity and yields of reef fishing. In: Polunin NVC, Roberts CM (eds) Reef fisheries. Chapman \& Hall, London, p 161-192

DAR (Division of Aquatic Resources) (1988) Main Hawaiian Islands-Marine Resources Investigation 1988 Survey. Division of Aquatic Resources, Department of Land and Natural Resources, Honolulu, HI

DeMartini EE, Friedlander AM, Holzwarth SR (2005) Size at sex change in protogynous labroids, prey body size distributions, and apex predator densities at NW Hawaiian atolls. Mar Ecol Prog Ser 297:259-271

Division of Fish \& Game (1977) Hawaii Revised Statutes. Regulation 45: Concerning the establishment, maintenance, management, and operation of the Waikiki-Diamond Head Shoreline Fisheries Management Area, Island of Oahu. Department of Land and Natural Resources, Honolulu, HI

Edgar GJ, Barrett NS (1999) Effects of the declaration of marine reserves on Tasmanian reef fishes, invertebrates and plants. J Exp Mar Biol Ecol 242:107-144

Friedlander AM, DeMartini EE (2002) Contrasts in density, size, and biomass of reef fishes between the northwestern and the main Hawaiian islands: the effects of fishing down apex predators. Mar Ecol Prog Ser 230:253-264

Friedlander AM, Parrish JD (1997) Fisheries harvest and standing stock in a Hawaiian bay. Fish Res 32:33-50

Friedlander AM, Parrish JD (1998) Habitat characteristics affecting fish assemblages on a Hawaiian coral reef. J Exp Mar Biol Ecol 224:1-30

Friedlander AM, Ziemann DA (2003) Impact of hatchery releases on the recreational fishery for Pacific threadfin (Polydactylus sexfilis) in Hawaii. Fish Bull (Wash DC) 101:32-43

Friedlander AM, Brown EK, Jokiel PL, Smith WR, Rodgers KS (2003) Effects of habitat, wave exposure, and marine protected area status on coral reef fish assemblages in the Hawaiian archipelago. Coral Reefs 22:291-305

Harman RF, Katekaru AZ (1988) 1987 Hawaii Commercial Fishing Survey. Division of Aquatic Resources, Department of Land and Natural Resources, Honolulu, HI

Hart DR (2003) Yield- and biomass-per-recruit analysis for rotational fisheries, with an application to the Atlantic sea scallop (Placopecten magellanicus). Fish Bull (Wash DC) 101:44-57

Johannes RE (1978) Traditional marine conservation methods in Oceania and their demise. Annu Rev Ecol Syst 9:349-354

Kulbicki M, Sarramegna S (1999) Comparison of density estimates derived from strip transect and distance sampling for underwater visual censuses: a case study of Chaetodontidae and Pomacanthidae. Aquat Living Resour 12:315-325

Maly K, Pomroy-Maly O (2003) Ka Hana Lawai'a a me na Ko'a o na Kai'Ewalu. A history of fishing practices and marine fisheries of the Hawaiian Islands. The Nature Conservancy, Honolulu, HI

McCallum HI (1988) Pulse fishing may be superior to selective fishing. Math Biosci 89:177-181

McClanahan TR (2000) Recovery of a coral reef keystone predator, Balistapus undulatus, in East African marine parks. Biol Conserv 94:191-198

McClanahan TR, Arthur R (2001) The effect of marine reserves and habitat on populations of east African coral reef fishes. Ecol Appl 11:559-569

McClanahan TR, Graham NAJ (2005) Recovery trajectories of coral reef fish assemblages within Kenyan marine protected areas. Mar Ecol Prog Ser 294:241-248

McClanahan TR, Mangi S (2000) Spillover of exploitable fishes from a marine park and its effect on the adjacent fishery. Ecol Appl 10:1792-1805
Meyer CG (2003) An empirical evaluation of the design and function of a small marine reserve (Waikiki Marine Life Conservation District). PhD thesis, University of Hawaii, Honolulu, HI

Myers RA, Fuller SD, Kehler DG (2000) A fisheries management strategy robust to ignorance: rotational harvest in the presence of indirect fishing mortality. Can J Fish Aquat Sci 57:2357-2362

Polunin NVC, Roberts CM (1993) Greater biomass and value of target coral-reef fishes in two small Caribbean marine reserves. Mar Ecol Prog Ser 100:167-176

Roberts CM, Bohnsack JA, Gell F, Hawkins JP, Goodridge R (2001) Effects of marine reserves on adjacent fisheries. Science 294:1920-1923

Russ GR, Alcala AC (1996) Do marine reserves export adult fish biomass? Evidence from Apo Island, central Philippines. Mar Ecol Prog Ser 132:1-9

Russ GR, Alcala AC (1998) Natural fishing experiments in marine reserves 1983-1993: community and trophic responses. Coral Reefs 17:383-397

Russ GR, Alcala AC (1999) Management histories of Sumilon and Apo marine reserves, Philippines, and their influence on national marine resource policy. Coral Reefs 18: 307-319

Russ GR, Alcala AC (2003) Marine reserves: rates and patterns of recovery and decline of predatory fish, 19832000. Ecol Appl 13:1553-1565

Russ GR, Alcala AC (2004) Marine reserves: long-term protection is required for full recovery of predatory fish populations. Oecologia 138:622-627

Russ GR, Alcala AC, Maypa AP (2003) Spillover from marine reserves: the case of Naso vlamingii at Apo Island, the Philippines. Mar Ecol Prog Ser 264:15-20

Russ GR, Alcala AC, Maypa AP, Calumpong HP, White AT (2004) Marine reserve benefits local fisheries. Ecol Appl 14:597-606

Sadovy YJ (1996) Reproduction of reef fishery species. In: Polunin NVC, Roberts CM (eds) Reef fisheries. Chapman \& Hall, London, p 15-60

Shomura R (1987) Hawaii's marine fishery resources: yesterday (1900) and today (1986). NMFS Administrative Report H-87-21, US Department of Commerce, NOAA, National Marine Fisheries Service Southwest Fisheries Science Center, La Jolla, CA

Shomura R (2004) A historical perspective of Hawaii's marine resources, fisheries, and management issues over the past 100 years. Honolulu, Hawai. In: Friedlander AM (ed) Status of Hawaii's coastal fisheries in the new millennium. Proceedings of a symposium sponsored by the American Fisheries Society, Hawaii Chapter, Honolulu, HI, p 6-11

Sladek Nowlis J, Friedlander AM (2005) Marine reserve function and design for fisheries management. In: Norse EA, Crowder LB (eds) Marine conservation biology: the science of maintaining the sea's biodiversity. Island Press, Washington, DC, p 280-301

Sluczanowski PR (1984) A management-oriented model of an abalone fishery whose substocks are subject to pulse fishing. Can J Fish Aquat Sci 41:1008-1014

Smith JE, Hunter CL, Conklin EJ, Most R, Sauvage T, Squair C, Smith CM (2004) Ecology of the invasive red alga Gracilaria salicornia (Rhodophyta) on O'ahu, Hawai'i. Pac Sci 58:325-343

Williams ID, Polunin NVC (2000) Differences between protected and unprotected reefs of the western Caribbean in attributes preferred by dive tourists. Environ Conserv 27: 382-391

Submitted: April 26, 2005; Accepted: August 12, 2005

Proofs received from author(s): March 8, 2006 